\title{
AJARAN AGAMA HINDU SEB AGAI INSPIRASI PENCIPTAAN KARYA SENI LUKIS TRADISIONAL BALI
}

\author{
I Wayan Agus Gunada \\ Program Studi Pendidikan Agama Hindu Jurusan Dharma Acarya \\ Sekolah Tinggi Agama Hindu Negeri Gde Pudja Mataram \\ Jl. Pancaka No. 7b, Kota. Mataram, Kode Pos 83126 \\ Nusa Tenggara Barat. Indonesia \\ Email: gunadastahngpmataram@gmail.com
}

\begin{abstract}
Abstrak
Penelitian ini merupakan bentuk analis is serta kajian mengenai peran ajaran agama Hindu dalam proses penciptaan karya seni lukis umumnya seni lukis tradisional Bali. Seni lukis sebagai bagian dari seni rupa di Bali berkembang cukup pesat, dimana terdapat dua dikotomi seni lukis di Bali yaitu seni lukis tradisional di Bali dan Seni lukis modern. Seni lukis tradisional Bali merupakan bentuk seni lukis yang proses pembuatannya masih menggunakan tradisi-tradisi baik proses pembuatan dan bahan-bahan y ang tradisional walaupun kini sudah umum ditemukan menggunakan alat serta bahan yang sudah tergolong modern, dan seni lukis tradisional Bali ini yang sudah berlangsung sejak dulu yaitu terdapat pakem-pakem serta prinsip yang dilakukan ketika proses penciptaan karya tersebut dikreasikan. Ketika seorang pelukis mencipta sebuah karya maka realita dan imajinasi menjadi sumber ide namun Seni lukis tradisional Balimemiliki ciri khasnya yang sangat kentara ketika dilihat secara langsung, yaitu penggambaran objek bentuk karyanya yang cenderung mengambil bentukbentuk alam, cerita-cerita rakyat, mitologi serta ajaran-ajaran agama Hindu yang direinterpretasikan melalui bentuk simbol-simbol didalamnya. Sehingga sebagian besar tema-tema yang dihadirkan dalam seni lukis tradisional Bali adalah mengimajinasikan ajaran-ajaran agama Hindu yang kental akan nilai-nilai spiritual dan memiliki nilai-nilai magis kedalam sebuah karya yang tidak hanya sekedar memuas kan pengalaman keindahan namun secara tidak lang sung juga menjadi media wahana pengajaran ajaran agama Hindu. Penelitian ini bertujuan untuk menggambarkan bagaimana ajaran agama Hindu menjadi sumber ins pirasi dalam penciptaan karya seni lukis tradisional Bali. Metode yang digunakan dalam mengkaji fokus penelitian ini adalah metode penelitian kualitatif deskriftif dengan pendekatan studi fenomenologi yaitu penelitian menggunakan data-data kualitatif untuk meng gambarkan fenomena-fenomena ajaran agama Hindu y ang menjadi sumber ins pirasi penciptaan. Secara pragmatis penelitian ini diharapkan berdampak dalam memberikan informasi dan menambah wawas an terkait keberadaan senilukis tradisional Bali sebagaibentuk kekayaan budaya bidang seni yang masih hidup serta keberadaannya yang masih lestari dan hidup di Bali.
\end{abstract}

Kata Kunci: hindu, seni, lukis tradisional, bali.

\begin{abstract}
This research is a form of analysis and study of the role of the Hindu religion in the process of creation of art painting generallytraditional Balinese painting. Art painting as partof the art in Bali develops quite rapidly, where there is two art dichotomy in Bali is a traditional art painting in Bali and the art ofmodern paint. Traditional Balinese painting is a form of art painting that process is still using the traditions of both the making process and traditional materials although it is now common to be found using tools and materials that are already relativelymodern, and the traditional Balinese painting that has been held since the first time is there are pakem and the principle that is done when the process of creation of the work is Reincreikan. When a painter creates a masterpiece, the reality and imagination become the source of ideas but the traditional Balinese painting has its distinctive characteristic when viewed directly, that is the depiction of the object of his form that tends to take the forms ofnature, folklore, mythology, and teachings of Hindu religion that is interpreted by the form of symbols inside. So most of the themes presented in the art of traditional Balinese painting are too imaginative Hindu teaching s that are strong in spiritual values and have magical values into a work that not only satisfies the experience of beauty but indirectly also becomes a medium of religious teaching of Hindu teachings. This research aims to illustrate how Hinduism's teachings are a source of inspiration in the creation of traditionalBalinese art paintings. The method used in reviewing the focus of this research is a qualitative method of research with the approach of phenomenology study using qualitative data to describe the phenomena ofHindu religious teaching s that are the source of
\end{abstract}


the inspiration of creation. Pragmatic research is expected to have an impact on providing information and adding insight related to the existence of traditional Balinese art painting as a form of cultural richness of living arts and its existence that is still sustainable and living in Bali.

Keywords: hindu, art, traditional painting, bali

\section{PENDAHULUAN}

Keindahan Bali sebag ai sebuah tujuan destinasi wis ata dunia bukan hanya terletak pada keindahan alamnya semata namun yang lebih menjadi tujuan dari para pelancong dunia adalah keindahan budayanya yang unik dengan seni menjadi center of the interest atau pusat ketertarikannya. Seni di Bali tidak hanya sekedar bertujuan pada ekspresi pencipta melalui media-media untuk pemuas rasa keindahan semata namun seni di Bali menjadi semacam media dalam penyampaian dan wahana pengajaran agama Hindu.

Sulismadi dan Sofwani menjelaskan bahwa Kebudayaan merupakan cipta, rasa dan kars a manusia (Sulismadi dan Sofwani, 2011:5). Ini menandakan bahwa budaya dan kebudayaan merupakan suatu tradisi yang berlangsung turun-temurun yang merupakan hasil olah rasa, olah cipta dan olah karsa yang kemudian menjadi legacy atau waris an manusia sekarang. Inilah yang terjadi di Bali, seni sebagai bagian dari unsurbudaya merupakan proses cipta rasa dan karsa manusia yang dalam perkembangannya selalu bersinergi deng an unsur religi sehingga seni di Bali bukan hanya sekedar karya seni, namun juga menjadi suatu media pendidikan agama dan menjadi sarana dalam ritual keagamaan Hindu di Bali.

Sabatari menjelaskan bahwaseni adalah segala bentuk keindahan yang diciptakan oleh seorang manusia (Sabatari, 2015:2). Secara Filosofis dalam beberapa literatur disebutkan bahwa kata seni berasal dari bahasa Sanskerta yaitu kata "Sani" yang berarti pemujaan, persembahan dan lain-lain. Sehingga dapat dimaknai bahwa seni di Bali merupakan suatu persembahan yang dilakukan sebagai bentuk media bakti umat Hindu. Hal ini menyimpulkan bahwa sebagai sebuah keindahan seni merupakan suatu persembahan melalui pengalaman rasa indah yang digunakan sebagai media persembahan dalam prosesi keagamaan di Bali.

Burhan menyebutkan bahwa perkembangan seni lukis Bali yang merupakan tradisitelah berkembang akibat adanya interaksi dengan para pelancong utamanya para pelukis-pelukis Eropa yang mengubah prinsip kesenian Bali dari ciri sakralnya mengarah kepada fungsiprofan(Burhan, 2013:1). Lebih lanjut Adnyana menjelaskan bahwa perkembangan seni lukis Bali karena adanya interaksi yang begitu mendalam antara pelukis Bali dengan pelukis Eropa seperti Walter Spies dan Rudolf Bonet hingga berkembang dan lahirlah arena seni Pita Maha pada tahun 1936 (Adnyana, 2015:250). Sehingga dapat disimpulkan bahwa secara teoritis perkembang an seni lukis di Bali telah melalui berbagai tahap perkembangan sehingga sampai mencapai bentuknya seperti sekarang. Hal ini dapat dimaknai bahwa keberadaan seni lukis di Bali telah mengalami perkembangan yang cukup pesat, perkembangan inis angat dipengaruhi oleh interaksiinteraksi pelukis Bali dengan pelukis Eropa yang kemudian mengubah wajah seni lukis Bali yang dulunya sangat sakral menjadi profan.

Perkembang an yang begitu signifikan yang mengubah wajah senilukis Bali, nyatanya tidak juga mengubah ide-ide inspirasipenciptaan senilukis tradisionalyang utamanya bersumber dari wajah kehidupan sosial masyarakat Bali zaman dulu yang kental akan nilainilai tradisional dan juga yang sangat kental merupakan bentuk adaptasi dan representasi ajaranajaran agama Hindu, sehingga secara empiris wajah seni lukis tradisional Bali masih memunculkan simbol-simbol ajaran agama Hindu dalam penggambaran lukisannya melalui bentuk-bentuk wayang yang seringkali menampilkan lakon Itihasa Ramayana dan Mahabharata serta berbagai mitologimitologi Hindu serta Bali.

Penelitian ini secara pragmatis bertujuan dalam menggambarkan bagaimana ajaran agama Hindu menjadi ide serta inspirasi penciptaan karya seni lukis tradisional Bali dan secara sederhana menggambarkan proses penciptaan karya seni lukis tradisional Bali yang terinspirasi melalui ajaran-ajaran agama Hindu. Dalam proses pengkajian seni lukis tradisional Bali ini lebih menekankan kepada aspek keberadaan ajaran agama Hindu sebagai suatu ide, tema dan inspirasi dalam penciptaan sebuah karya. Penelitian ini pula diharapkan dapat menjadi sebuah kajian serta wahana wawasan dalampengembangan kajian-kajian terhadap senikhususnya seni rupa bidang seni lukis tradisional Bali dan dan dapat menjadi suatu pu staka rujukan bagi penelitian-penelitian sejenis dimasa mendatang. 


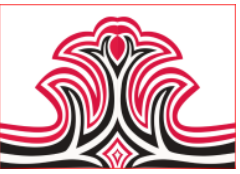

\section{KAJIAN TEORI}

Menurut Purwadarminta dalam Sams uri menyebutkan bahwa teorimerupakan pendapat, as as, hukum yang menjadi suatu dasar dan sebagai cara dalam melakukan sebuah kegiatan (Samsuri, 2003:1). Maka dapat disimpulkan bahwa teori merupakan suatu pandangan yang menjadi acuan dalam suatu kegiatan maka dalam hal ini adalah penelitian. Dalam penelitian terkait ajaran agama Hindu sebag ai ins pirasi dalam penciptaan karya seni lukis tradisional Bali maka terdapat tiga teori sebagai pisau bedah yaitu teori simbol sebagai pisau bedah untuk membahas reinterpretasi simbol sebagai ajaran agama hindu dan maknanya, teori religi untuk membahas sistem kepercayaan agama Hindu yang sarat akan simbolsimbol dalam pelaksanaan keagamaannya dan teori penciptaan seni rupa sebagai teori proses pembentukan karya seni lukis tradis ional Bali, adapun teori-teori tersebu sebagai berikut:

\section{Teori Simbol}

Saifuddin dalam Haris dan Amalia (2018) menyebutkan bahwa simbol merupakan alat komunikasi atau sarana komunikasi melalui suatu tanda dan bentuk sebagai media menyampaikan pengetahuan dan pesan (Haris \& Amalia, 2018:17).

Simbol menurut Cassirer dalam Yanti Kusuma Dewi (2016) adalah realitas yang ditangkap melalui pengalaman dan membentuk simbolyang membentuk kebudayaan (Yanti Kusuma Dewi, 2016:64). Beberapa pandangan mengenai simbol diatas maka dapat disimpulkan bahwa simbol merupakan suatu reinterpretasi alam dimana alam kemudian dibahasakan melalui simbol-simbol yang memiliki makna sebagai media dan wahana dalam menyampaikan suatu pesan.

Berkaitan dengan simbol dan hubungannya dengan keagamaan maka sistem religi menjadi suatu dasar dalam penggunaan simbol. Koentjaraningrat dalam Pratiwi (2017) menyebutkan bahwa dalamprosesnya seseorang terikat akan emosi keagamaan yang menyebabkan individu-individu berperilaku yang berhubungan dengan religi, lebih lanjut bahwa sistem religi tersebut terdiri atas emosi keagamaan, sistem kepercayaan, sistem upacara dan kelompok keagamaan (Pratiwi, 2017:176). Maka dapat disimpulkan bahwa sistem religi berkaitan dengan suatu perilaku yang dilakukan masyarakat karena disebabkan adanya emosi keagamaan. Agama Hindu terkait dengan sistem religi pada proses pelaksanaan keagamaannya selalui berhubungan dengan emosi keagamaan yang dirasakan oleh penganutnya di Bali,
Gorga : Jurnal Seni Rupa

Volume 09 Nomor 01 Januari-Juni 2020

p-ISSN: $2301-5942$ | e-ISSN: 2580-2380

yang kemudian diwujudkan melalui sistem-sistem kepercayaan dan pelaksanaan ritual yang didalamnya terdapat ajaran-ajaran etika (susila) dan bersumber dari fils afat Hindu (tatwa).

Proses ritualyang sedemikian rupa dalam prosesnya melibatkan kesenian sebagai bentuk media atau sarana dalam proses pelaksanaan ritual keagamaannya, sehingga karyaseni y ang tercipta umumnya dan karya seni lukis tradisional Bali terinspirasi dari ajaranajaran suci Hindu dan menjadi bagian dari pelaksanaan keagamaan Hindu Agama Hindu dalam proses keagamannya menggunakan simbol-simbol yang terbentuk dalam berbagai wujud, keterbatas an manusia dalammemahami semesta ciptaan Tuhan ini disederhanakan melalui bentuk simbol-simbol suci, sehingga dapat dimaknai bahwa simbol merupakan suatu bentuk penyajian kembali alam melalui simbol y ang memiliki makna dan ajaran-ajaran agama Hindu inilah yang kemudian oleh para perupa dijadikan sebagai suatu inspirasi untuk mencipta karya melalui reinterpretasi ajaran agama Hindu kedalam sebuah lukis an yang mengandung makna dan menjadi media pembelajaran dan penyampaian ajaran agama Hindu.

\section{Teori Penciptaan Seni Rupa}

Is tilah seni rupa merupakan is tilah seni yang merujuk kepada seni dalam perwujudannya melalui bentukbentuk rupa yang dapat dilihat dan diraba. Seni sebagai suatu cipta rasa dan kars a manusia dalam seni rupa diwujudkandan dimediakan melalui bidang dua dan tiga dimensi. Menurut Rupiani, Suteja dan Wimbaruspati menyebutkan bahwa dalam menciptakan sebuah karya seni maka harus diketahui segala proses-proses dalam berkesenian sehingga dapat mempermudah dan membantu dalam menciptakan sebuah karya seni (Rupiani, Suteja, \& Wimbaruspawati, 2017:139).

Desmond dalam Rondhi (2017) menyebutkan bahwa seni merupakan hasil karya manusia atau hasil ekspresi dan ungkapan jiwa manusia namun dalam prosesnya tidak semuahasil kary a seni dapat disebuat dan dikatakan sebuah hasil seni (Moh. Rondhi, 2017:10). Lebih lanjut Zulfi Hendri (2013) menjelaskan bahwakarya seni rupa merupakan objek estetis y ang dibagun dan dibentuk berdas arkan garis, warna, shape, dan beberapa unsur lain (Zulfi Hendri, 2013:3).

Dari tiga pandangan diatas maka dapat disimpulkan bahwa karya seni rupa kaitannya dengan penciptaan sebuah karya maka harus didasarkan atas pengetahuan terhadap proses penciptaan berdas arkan unsur-unsur 
yang membentuknya sehingga karya seni rupa yang tercipta merupakan sebuah hasil karya seni karena tidak semua yang diciptakan oleh manusia dapat dikatakan sebagai karya seni. Karya seni rupa jika ditinjau dari sifatnya maka terdiri atas seni murni dan seni terapan. Teori penciptaan seni rupa mengacu kepada pendapat ataupun pedoman dalam berkarya seni rupa khususnya s eni lukis. Dalam penciptaan s eni rupa terdapat beberapa unsur yang harus dipenuhi diantaranya titik, garis, bidang, ruang, warna dan tekstur serta dipadukan dengan prinsip kesatuan, harmoni, irama, keseimbangan dan kontras. Perpaduan antara unsur dan prinsip inilah yang kemudian menjadi ciri dari sebuah karya seni rupa.

Senilukis tradisional Bali sebagai bagian dari waris an budaya Bali yang masih hidup dan berkembang di Bali dalam proses penciptaannya melalui beberapa proses yang sudah menjadi pakem yang baku karena dilakukan atas mekanisme tradisional, baik cara berkarya maupun dari segi alat dan bahan yang mas ih tradisional. Perkembangan zaman yang begitu pesat juga turut mempengaruhilukis tradis ional Bali dimana telah terjadi pergeseran baik teknik, alat maupun bahan yang digunakan namun tidak mengubah ciri dari lukis tradisional Bali ters ebut. Secara sederhana maka dalam penciptaan karya seni lukis tradisional Bali terdapat beberapa proses yaitu proses awal dimana seniman atau undagi mulai mencipta yang diawali dalam pencarian atau explorasi ide, dilanjutkan proses penyiapan alat dan bahan, proses berkarya melalui beberapa tahapan dan terakhir adalah finishing.

\section{METODE PENELITIAN}

Penelitian inimerupakan penelitian berjenis kualitatif yang menggunakan pendekatan studi fenomenologi. Trumbuldan Watson dalam dala, Azmi, Nasution dan Wardayani (2018) menyebutkan dan menyatakan bahwa penelitian kualitatif merupakan metode dengan beraneka segi fokus (Azmi, Nasution, \& Wardayani, 2018:161). Lebih lanjut kemudian Subandi menyebutkan dalam ranah penelitian sosial, pendekatan kualitatif merupakan jenis penelitian yang memerlukan data berupa informasi dalam bentuk deskrifttif (Subandi, 2011:173). Maka dapat disimpulkan bahwa penelitian kualitatif merupakan jenis penelitian pada segifokus yang cukup beragam, dimana dalam penelitian ini penelitian kualitatif ini menggunakan studi fenomenologi untuk menggambarkan secara pasti fenomena bagaimana ajaran agama Hindu menjadi sumber inspirasi dalam penciptaan karya seni lukis tradisional Bali.
Terdapat dua jenis data yang digunakan yaitu data primer dan sekunder dan menggunakan dua teknik pengambilan data yaitu observasi dan studi pustaka terhadap kepustakaan yang relevan dengan bidang penelitian dan peneliti menjadi instrumen kunci. Dalam menganalisis data digunakan teknik reduksi data yaitu memilah dan memilih data yang relevan dengan penelitian, penyajian data yaitu menyajikan data dalampola-pola s esuai permasalahan dan terakhir adalah verivikasi data yaitu menyimpulkan data dan menginterpretasikan data. Selain teknik tersebut untuk mendapatkan data yang valid dan basah maka digunakan pula teknik trianggulasi data sebagai alat analisis untuk mendapatkan data yang original dalam subjek penelitian.

\section{HASIL DAN PEMBAHASAN \\ 1.Hasil}

Seni lukis tradisional Bali yang berkembang di Bali memiliki keunikan tersendiri dimana dalam proses pembuatannya yang umumnya masih menggunakan teknik-teknik tradisional dan umumnya pencitraan bentuk objek lukis annya terletak kepada perwujudan pola-pola wayang tradisional untuk menggambarkan cerita ataupun tema yang ingin dis ampaikan oleh sang undagi.

Undagi merupakan istilah bagi seniman di Bali yang berkutat dibidang senirupa, is tilah undagi pun tidak sembarangan di sematkan pada seorang seniman seni rupa karena proses menjadi seorang undagi harus menjalani proses-proses ritual suci karena karya yang tercipta dari seorang undagi tidak hanya berfungsi sebagai karya seni semata namun karya seni yang dikreasikan dan diciptakan oleh seorang undagi berfungsi sebagai sarana ritual keagamaan seperti pembuatan bade yaitu pengusungan jenasah di Bali yang merupakan karya seni arsitektur namun fungsinya tidak hanya sebagai karya seni namun memili fungsi sebagai s arana ritual atau upacara pada upacara ngaben, bentuk lain karya seni undagi dalam bidang seni rupa adalah petulangan, kober, kajang dan lain-lain..

Seni lukis tradisional Bali yang dibuat oleh seorang undagi pada das arnya merupakan sebuah karya seni ungkapan perasaan emosional yang diekspresikan melalui bentuk-bentuk dan teknik-teknik tradisional Bali yang didalamnya bukan hanya memiliki makna keindahan semata namun terdapat juga nilai-nilai pendidikan keagamaan sebagai media dan wahana pengajaran ajaran suci Hindu. Ini telah dibuktikan dalam penelitian penulis sebelumnya yang berjudul "Ajaran Agama Hindu dalam Geguritan Candra 


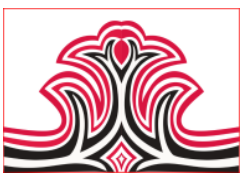

Bherawa Sebagai Penguatan Pendidikan Karakter" ditemukan bahwa karya seni sastra geguritan bukan hanya sekedar kary a s astra sebagai bentuk pemenuhan pengalaman keindahan semata namun terdapat kandungan ajaran-ajaran suci utamanya nilai-nilai etika yang dapat dijadikan pedoman dalam internalis asipendidikan karakter (Gunada, 2020). Hal ini dapat dimaknai bahwa setiap karya seni Bali yang tercipta tidak hanya sebagai bentuk cipta rasa karsa manusia pemuasaan pengalaman keindahan semata, namun karya seni yang tercipta yang terinpirasi melalui ajaran-ajaran suci Hindu memiliki fungsi sebagai media pengajaran keagamaan yang sarat akan nilai filosofis dan nilai-nilai etika.

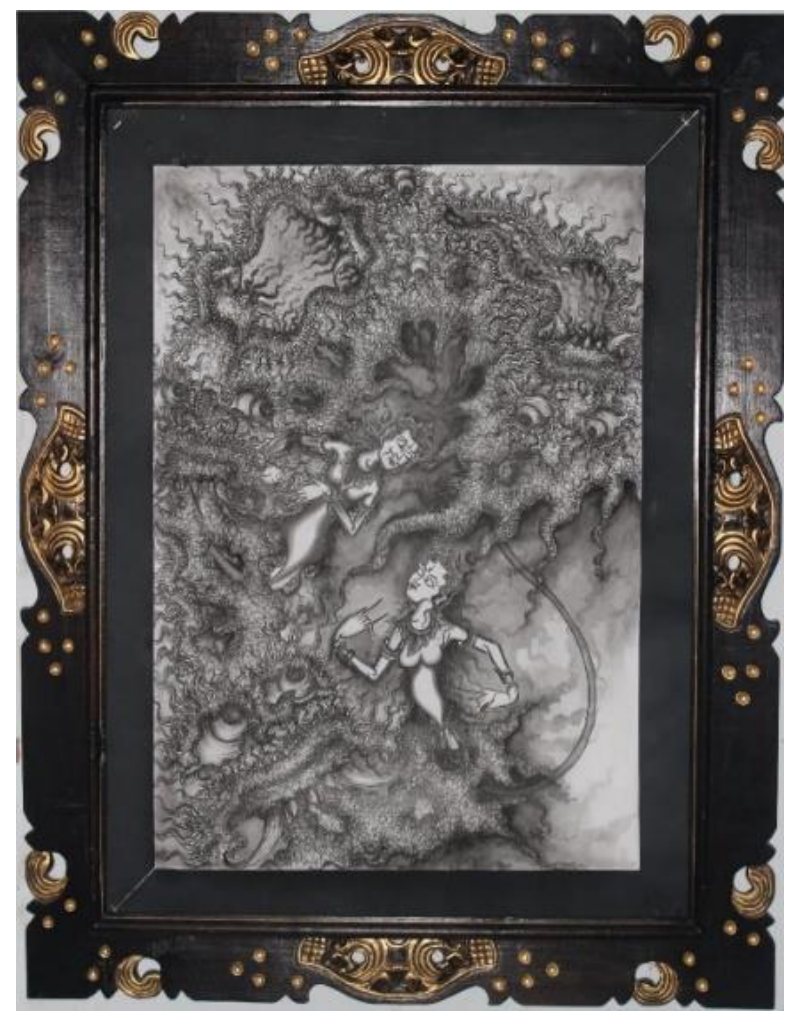

Gambar 1. Lukisan dengan Judul "Purusa Pradhana" (Sumber : I Wayan Agus Gunada, 2020)

Seperti yang terlihat pada gambar 1, lukisan dengan Judul Purusa Pradhana, lukisan ini merupakan karya peneliti sendiri yang bercerita tentang konsep kosmologi atau penciptaan alam semesta menurut ajaran agama Hindu. Purusa melambangkan unsur pas if yang disimbolkan dengan bentuk wayang lakilaki, dan pradhana sebagai unsur aktif yang disimbolkan dengan bentuk wayang perempuan. Purusa merupakan unsur rohani atau kejiwaan dan pradhana merupakan unsur jasmani atau kebendaan. Bertemunya purusa dan pradhana inilah yang menciptakan harmonisasi dan menciptakan keberadaan dari ketiadaan. Simbolisasi purusa dan
Gorga : Jurnal Seni Rupa

Volume 09 Nomor 01 Januari-Juni 2020

p-ISSN: $2301-5942$ | e-ISSN: 2580-2380

pradhana dapat disederhanakan dalam konsep penciptaan manusia dan keberadaan manusia. Unsur purusa dalam bentuk Laki-laki yang mengeluarkan kama petak (sperma) dan pradhana dalam bentuk perempuan yang mengeluarkan kama bang (ovum) pertemuan antara kama bang dan kama petak inilah yang kemudian menghasilkan manik yaitu calon bayi yang sering disebut dengan embrio. Embrio yang berkembang ini kemudian dalambeberapa bulan akan lahir menjadi seorang bayi.

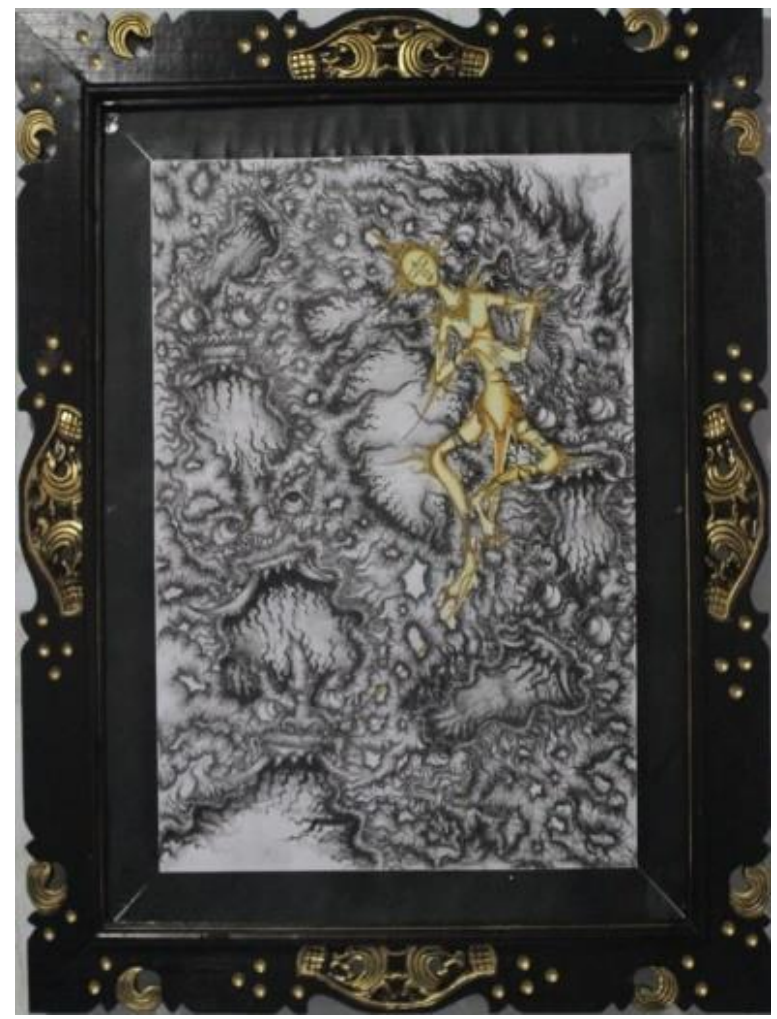

Gambar 2. Lukisan dengan Judul "Acintya" (Sumber : I Wayan Agus Gunada, 2020)

Lukis an pada gambar 2 merupakan lukis an tradisional Bali karya peneliti sendiri yang berjudul "Acintya", acintya merupakan konsep Tuhan dalam kepercayaan Agama Hindu, Tuhan atau dalam Hindu disebut dengan brahman yang merupakan pencipta alam semesta, daribrahman seluruh alam semesta tercipta dan kepada brahman maka alam semesta akan melebur kembali. Keberadaan Tuhan yang tidak dapat dilihat namun dapat diras akan kemudian disimbolis as $\mathrm{i}$ dalam wujud acintya yang bermakna ia yang tidak terpikirkan, karena tidak terpikirkan maka disimbolkan dengan wujud ardhanareswari dia yang tidak laki-laki maupun perempuan. Simbol acintya sering ditemukan dalam sarana-sarana suci Hindu sepertipura pada pelinggih padmasana, rerajahan, ulap-ulap. Lukisan ini divis ualisasikan dengan acintya yang berwarna kuning keemasan yang bermakna 


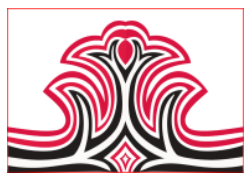

bahwa Tuhan merupakan pencipta alamsemesta yang mulia dan suci, simbol-simbol raksasa yang mengelilingi acintya merupakan visualisasi dari energi-energinegatif maupun positif, yang bermakna bahwa kebaikan dan keburukan bersumber dari Tuhan, namun Tuhan tidak terpengaruh oleh ciptaannya karena pada dasarnya Tuhan adalah kesucian itu sendiri. Wyapaki wyapaka nirwikara, Tuhan berada dimana-mana dan meres api segala ciptaannya.

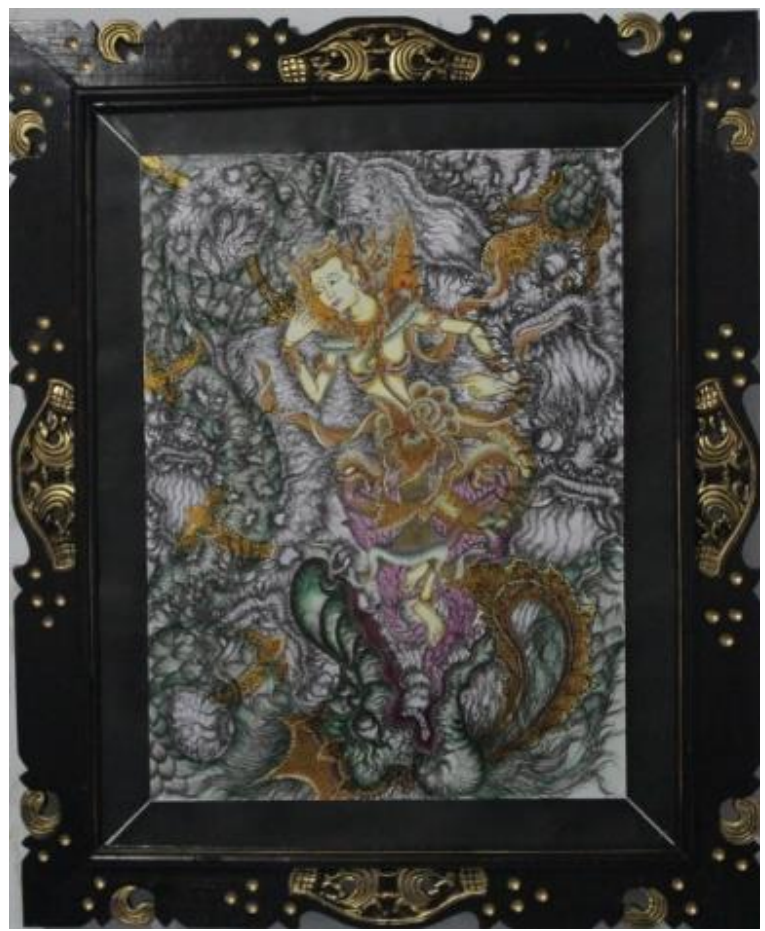

Gambar 3. Lukisan dengan Judul "Sutasoma Katadah" (Sumber : I Wayan Agus Gunada, 2020)

Lukis an pada gambar 3. Merupakan lukis an peneliti yang berjudul "Sutasomakatadah" merupakan lukis an yang mengambil sumber inspirasi kisah Sutasoma. Kis ah Sutasoma menceritakan Sutas oma yang dalam perjalananny a dengan sukarela dimakan oleh seorang naga karena sang naga saking laparnya, namun karena kesungguhan hati dan keikhlas an hatinya Sutasoma hidup kembali dan melihat hal itu sang naga kemudian menjadi murid dari Sutas oma. Ini mengajarkan bahwa perbuatan baik harus dilandasi oleh keikhlas an hati tanpa mengharapkan imbalan maupun pamerih.

Rondhi menyatakan bahwa yang membuat sesuatu dapat dikatakan sebagai sebuah karya seni atau bukan karya senitidak terg antung kepada ciri fis ikny a namun lebih kepada makna yang terkandung dalamkarya seni tersebut (Mohammad Rondhi, 2014:118). Sehingga dari beberapa visualisasi lukisan diatas maka dapat disimpulkan bahwa ciri khusus seni lukis tradisional Bali adalah makna yang terkandung didalamnya dan
Gorga : Jurnal Seni Rupa

Volume 09 Nomor 01 Januari-Juni 2020

p-ISSN: 2301-5942 | e-ISSN: 2580-2380

ajaran agama Hindu dalam lukisan tradisional Bali merupakan sumber inspirasi utama dalam proses penciptaan karyanya. Visualisasi yang mengambil ajaran agama Hindu tidak hanya bertujuan untuk membuat suatu karya yang indah dan sedap dipandang mata saja, namun seorang pelukis tradisional Bali memiliki misi yang lain yaitu melalui simbolisasi serta visualisasi ajaran agama Hindu dalam lukisannya menjadi suatu transfer dan trans formasi ajaran agama Hindu kepada penikmat seni lukis. Sehingga seni bukan hanya sekedar pelampiasan keinginan keindahan sematanamun seni di Bali menjadi sumber penciptaan karya dan menjadi media dan sarana agama dalam transfer dan tranformasi ajaran sucinya.

\section{Pembahas an}

Proses penciptaan seni Lukis tradisional Bali melalui pengalaman, pengamatan serta wawancara pada seniman-seniman perupa Bali umumnya tidak melalui proses yang singkat, proses penciptaan bahkan bis a menghabiskan waktu hingga behari-hari bahkan berminggu-minggu. Ini dikarenakan bahwa terdapat sejumlah tahapan yang harus dilakukan untuk menciptakan lukisan tersebut. Berbeda dengan lukisan modern, seni lukis bali masih menggunakan teknikteknik tradis ional yang cukup dipertahankan sebagai ciri khasnya namun dalambeberapa kes empatan telah terjadi semacam perpaduan teknik antara teknik modern dengan teknik tradisional namun tidak mengubah secara keseluruhan konsep dan visualis asi lukis an tradisional Bali.

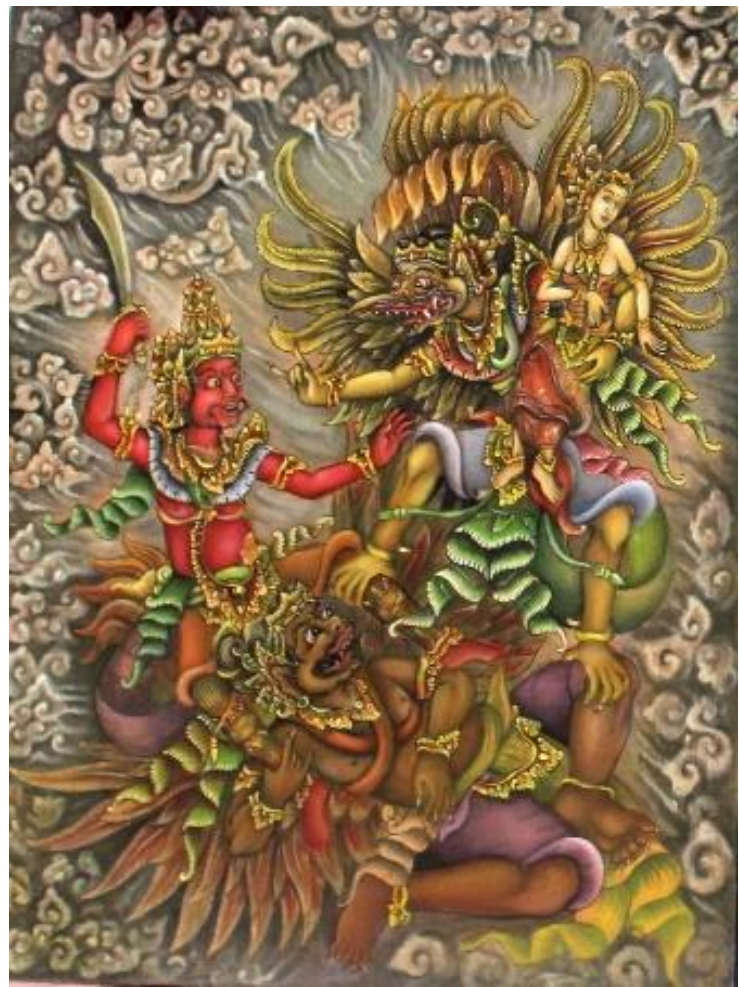




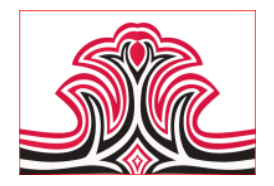

Gambar 4. Lukisan dengan Judul Jatayu Yudha (Sumber : I Wayan Mahardika, -------)

I Wayan Mahardika menuturkan bahwa proses dan tahap melukis seni lukis tradisional Bali telah mengalami perkembangan yang cukup signifikan, perkembangan ini umumnya terjadi karena terjadinya proses interaksi s eniman melalui berbagai proses $s$ alah satunya dengan pemilihan bahan serta alat seperti penggunaan cat acrylik serta kuas-kuas yang tergolong baru, namun masih banyak seniman yang masih menggunakan teknik-teknik tradisional salah satunya beliau, seperti s alah satu lukis an tradisional bali karya beliau denganjudul "Jatayu Yudha" (lihat gambar 4) dan "Garuda W is nu" (lihat gambar 5).

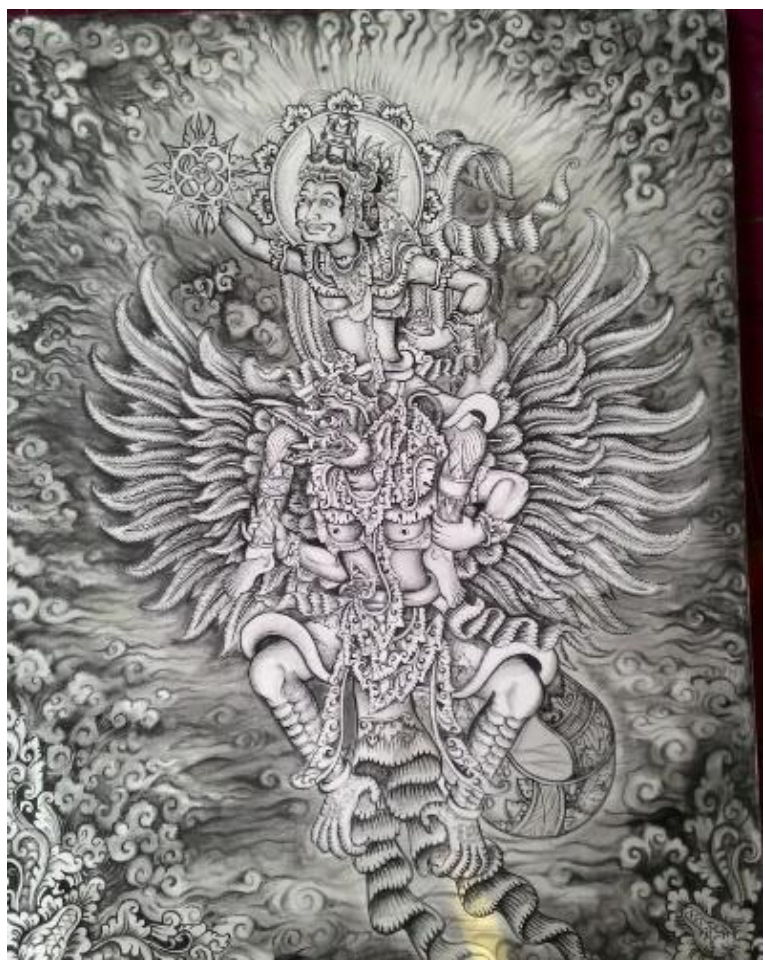

Gambar 5. Lukisan dengan Judul "Garuda Wisnu" (Sumber : I Wayan Mahardika, --------)

an indi Membuat Lukisan Tradisional Bali dalam prosesnya membutuhkan waktu yang cukup lama ini dikarenakan terdapat banyak tahap yang harus dilalui oleh seorang undagi atau seniman rupa Bali, pros es ini pun tergantung padajenis atau gaya lukis yang dibuat, karena dalamlukis tradisional Bali terdapat beberapa gaya diantara lukis tradisional Bali gaya Ubud, gaya Batuan, Gaya Kamasan. Masing-masing gaya memiliki ciri khas dan prosesnya.

Menurut Hendra dan Kaulam menyebutkan bahwa dalam melukis gaya kamasan terdapat beberapa tahap yaitu Mubuhin, Molokin yaitu mengatur komposis dan proporsi, Ngereka yaitu proses mengkontur garis,
Gorga : Jurnal Seni Rupa

Volume 09 Nomor 01 Januari-Juni 2020

p-ISSN: 2301-5942 | e-ISSN: 2580-2380

pewarnaan dan terakhir adalah nyawi yaitu memberikan ukiran pada objek (Made Hendra Sasmita dan Salamun Kaulam, 2016:181). Proses yang cukup panjang ini umumnya menghabiskan waktu yang panjang sehingga ciri lain dari lukis tradisional Bali adalah lama penciptaan karyanya

Pada gaya Ubud proses penciptaan karya juga melalui beberapa tahap dari awal hingga akhir penciptaan karyanya. Menurut I Wayan Mahardika, terdapat beberapaalat dan bahan yang digunakan yaitu media gambar dapat berupa kertas umumnya menggunakan kertas jenis concorde dan kanvas dimana kain yang umum digunakan yaitu kain drill, blacu ataupun jean, serta alat diantaranya kuas yang terbuat dari bambu yang dipukulmenggunakan palu hingga menghasilkan bulu-bulu pada ujungnya, pena bambu ataupun drawing pen, tinta mangsi, dan warna atau cat yang kini sudah umummenggunakan warna-warna cat jen is acrylic dan cat minyak.

a. Proses penyiapan bahan dan alat umumnya media kanvas dibuat sendiri

b. Sketsa dalam proses ini seniman mulai membuat desain berdasarkan tema yang sudah ditetapkan, proses sketsa dilakukan dengan membagi beberapa bidang pada media lukis untuk menentukan dimana letak objek akan digambar.

c. Selanjutnya adalah ngontur atau kontur yaitu menebalkan objek dengan pena bambu ataupun drawing pen.

d. Kemudian adalah mengabur atau abur, pada proses ini objek diberikan pewarnaan hitam dan putih secara transparan untuk memberikan kompos is i pencahay aan dan pewarnaan gelap bagi objek yang posisinya di belakang dan terang di depan.

e. Selanjutnya adalah ngeskes, proses ini merupakan lanjutan dari proses abur namun bertujuan lebih memberikan detail gelap terang pada objek sehingga benar-benar terlihat anatomi gelap terang pada objek.

f. Blok warna, proses ini dilakukan dengan memberikan satu warna yang dominan pada lukis an secara menyeluruh.

g. Pewarnaan, adalah memberikan warna sehingga mulai muncul detail-detal warna dari objek gambar.

h. Nyenter, setelah proses pewarnaan selesai maka selanjutnya adalah nyenter yaitu pemberian warna putih atau warna lain untuk memberikan kesan pencahayaan sehingga terlihat objek-objek yang lebih terang karena efek pencahayaan sehingga terdapat center of the interest 
i. Nyawi, proses ini dilakukan bertujuan untuk memberikan detail ukiran pada objek dengan tinta hitam sehingga terlihat batas-batas antara satu objek dengan objek lainnya

j. Proses terakhir adalah finishing, finishing dilakukan dengan memberikan figura sehingga menambah kesan estetika pada lukis an yang telah diciptakan.

Dapat disimpulkan bahwa dalam proses penciptaan karya seni lukis tradisional Bali, tahap penciptaan akan menyesuaikan dengan gaya lukis tradisional yang diciptakan, namun secara umum dalam penciptaannya terdapat proses -proses yang secara bertahap dilakukan untuk membuat karya yang memiliki nilai estetika tinggi.

\section{KESIMPULAN DAN SARAN 1.Kesimpulan}

Berdasarkan hasil penelitian dan pembahasan sebelumn ya maka dapat disimpulkan bahwa seni lukis tradisional Bali pada saat ini merupakan seni lukis yang telah berkembang akibat dari terjadinya interaksi seniman era dulu dengan para pelukis eropa yang kemudian mengubah bentuk dan wajah kesenian Bali dari sakral menuju profan.

Dari motivasi untuk ngayah menjadi motivasi ekonomis profanisme. Namun terlepas dari itu semua, senilukis tradisional Bali tetap eks is keberadaannya di Bali dan ajaran agama Hindu, kehidupan sosial masyarakat serta berbagai cerita rakyat dan mitologi Bali masih menjadiide utama dalampenciptaan karya seni. Proses penciptaan seni lukis tradisional Bali melalui beberapa tahapan yaitu proses pencarian ide melalui beragam media, penyiapan bahan dan alat, tahap sketsa, kontur, abur, ngekes, pemberian detail, pewarnaan, kontur detail dan finishing.

\section{Saran}

Keberadaan Seni Lukis Tradisional Bali sebagai waris an Budaya Bali harus mendapat perhatian serta us aha-u saha untuk terus dapatberkembang, eks is dan tetap lestari diBali. Us aha-usaha pelestarian ini tentu dapat dilakukan melalui berbagai usaha salah satunya di Bidang pendidikan seperti adanya sekolah seni serta perguruan tinggikesenian serta berbagai sanggar yang misi utamanyapembelajaran dan pelestarian kesenian Bali. Pelestarian dapat dilakukan melalui usaha-us aha pengkajian berbagai hasil karya seni khususnya seni lukis tradisional Bali. Sehingga dengan berbagai usaha dan peran semua pihak maka keberadaan seni khususnya seni lukis tradisional Balitetap dapat hidup dan menjadi suatu warisan budaya yang akan tetap menjadi daya tarik pariwis ata Bali bagi para penikmat seni.

\section{DAFTAR RUJUKAN}

Sulismadidan Ahmad Sofwani. 2011. Ilmu Sosial dan Budaya Dasar. Malang : UMM.

Adnyana, I. W. “Kun.” (2015). Arena Seni Pita Maha: Ruang Sosial dan Estetika Seni Lukis Bali 1930’an. Panggung, 25(3), 249-263. https://doi.org/10.26742/panggung.v25i3.22.

Azmi, Z., Nasution, A. A., \& Wardayani, W. (2018). Memahami Penelitian Kualitatif dalam Akuntansi. Akuntabilitas, 11(1), 159-168. https://doi.org/10.15408/akt.v 11i1.6338.

Burhan, M. A. (2013). Kelahiran Gaya Ubud dan Gaya Batuan dalam Seni Lukis Bali Pada Masa Kolonial Belanda. Dimensi, 10(1), 1-22.

Gunada, I. W. A. (2020). Ajaran Agama Hindu Dalam Geguritan Candrabherawa Sebagai Penguatan Pendidikan Karakter. Kamaya: Jurnal Ilmu Agama, 3(2), 102-119. https://doi.org/https://doi.org/10.37329/kamaya. v3i2.434.

Haris, A., \& Amalia, A. (2018). MAKNA DAN SIMBOL DALAM PROSES INTERAKSI SOSIAL (Sebuah Tinjauan Komunikasi). Jurnal Dakwah Risalah, 29(1), 16. https://doi.org/10.24014/jdr.v29i1.5777.

Made Hendra Sasmita dan Salamun Kaulam. (2016). Proses Dan Visualis asi Seni Lukis I Nyoman Mandra. Jurnal Seni Rupa, 4(02), 177-183.

Pratiwi, C. A. (2017). Harai : Telaah Konsep Religi Koentjaraningrat. Japanology, 5(2), 173-185.

Rondhi, Moh. (2017). Apres iasi Seni dalam Konteks Pendidikan Seni. Imajinasi, 11(1), 9-18.

Rondhi, Mohammad. (2014). Fungsi Seni bagi Kehidupan Manusia : Kajian Teoretik. Jurnal Imajinasi, VIII(2), 115-128.

Rupiani, N. W., Suteja, I. K., \& Wimbaruspawati, I. A. (2017). Ki Mantri Tutuan dalam Bentuk Karya Tari Inovatif Ki Mantra Tutuan in Form of Inovatif Dance. Kalangwan, 3(2), 135-141. https://doi.org/https://doi.org/10.31091/kalangw an.v3i2.237.

Sabatari, W. (2015). Seni: Antara Bentuk Dan Isi. Imaji, 4(2), 1-20. https://doi.org/10.21831/imaji.v4i2.6716

Samsuri, T. (2003). Kajian Teori, Kerangka Konsep Dan Hipotesis dalam Penelitian.

Subandi. (2011). Deskripsi Kualitatif Sebagai Satu Metode Dalam Penelitian Pertunjukan. Harmonia - Journal of Arts Research and Education, 11(2), 173-179. https://doi.org/10.15294/harmonia.v11i2.2210.

Yanti Kusuma Dewi. (2016). Simbol-Simbol Satanis me DalamPers pektif Teori Simbol Ernst Cassirer. Jurnal Filsafat, 19(1), 57-78. https://doi.org/10.22146/jf.3450. 